\title{
Effect of 20 Years of Low N Rate Pasture Fertilization on Soil Acidity
}

WILLIAM A. BERG

\section{Abstract}

Soil acidity resulting from nitrification of ammonium in fertilizer can limit plant growth. In this study on weeping lovegrass (Eragrostis curvula (Schrad.) Nees) and Caucasian bluestem (Bothriochloa caucasica (Trin.) Hubb) pastures on sandy soil in northwestern Oklahoma, 20 years of $N$ fertilization at an average rate of $37 \mathrm{~kg} \mathrm{~N} \mathrm{ha}^{-1} \mathrm{yr}^{-1}$ reduced the pH of the surface $5 \mathrm{~cm}$ of soil from 6.7 to 5.3. Sweetclover (Melilotus officinalis (L.) Lam.) and alfalfa (Medicago sativa $L$.) had symptoms of manganese toxicity when grown in the acidified soil in a glasshouse. The growth of warm-season grasses was not adversely affected when grown in the acidified soil. The lime requirement of the acidified soil was $896 \mathrm{~kg}$ $\mathrm{CaCO}_{3} \mathrm{ha}^{-1}$ greater than the lime requirement of adjacent unfertilized pastures. The lime requirements in relation to the amount of acid producing $\mathbf{N}$ fertilizer applied was similar to or less than lime requirements reported in the literature for larger $\mathbf{N}$ applications to farmlands. Continued use of $\mathrm{N}$ fertilizer at low rates will eventually require that once near-neutral soils be limed if species sensitive to acid soil are grown.

The acidification of near-neutral and slightly acid soils by repeated application of ammonium or ammonium-producing (urea) fertilizer is recognized as an emerging problem in dryland grain-growing areas of western North America (Mahler and Harder 1984, McCoy and Webster 1977, Westerman 1981). A similar problem with repeated $\mathrm{N}$ application to grassland soils was suggested by Owensby and Launchbaugh (1971), who cautioned that range soils often are not tillable, precluding mixing in of lime. They suggested avoiding a situation that cannot be easily rectified.

Nitrogen fertilized introduced grasses seeded into old farmlands can be important components in overall range management in higher precipitation areas of both the northern (Rogler and Lorenz 1974) and southern Great Plains (Berg and Coyne 1983). Nitrogen fertilization of native grasslands may be economically feasible under some conditions, particularly when cool-season grasses predominate (Rogler and Lorenz 1974). Newer concepts in grazing management such as intensive-early stocking (Launchbaugh et al. 1983) will place a greater demand for $N$ upon native range and eventually fertilizer $\mathrm{N}$ may be required to maintain productivity.

Nine years of fertilization with $\mathrm{NH}_{4} \mathrm{NO}_{3}$ at the rate of $34 \mathrm{~kg} \mathrm{~N}$ $\mathrm{ha}^{-1} \mathrm{yr}^{-1}$ reduced the $\mathrm{pH}$ of the surface $15 \mathrm{~cm}$ of a silt loam soil supporting native range from 6.5 to 6.1 (Smika et al. 1961). A similar soil $\mathrm{pH}$ change with comparable $\mathrm{N}$ rates was reported for another study also conducted near Mandan, North Dakota (Rogler and Lorenz 1969). Twenty years of $\mathrm{N}$ fertilization at the rate of $67 \mathrm{~kg} \mathrm{~N} \mathrm{ha}^{-1} \mathrm{yr}^{-1}$ decreased the $\mathrm{pH}$ in the surface $15 \mathrm{~cm}$ from 5.9 to 5.2 in a silt loam soil supporting smooth bromegrass near Manhattan, Kansas (Owensby et al. 1969).

Plant species and selections within species vary greatly in their sensitivity to acid soil conditions (Foy 1984). Some tall warmseason grasses are somewhat tolerant of acid soils and may only be affected below soil pH 4.5 to 5.0. Many legumes and especially alfalfa are sensitive to acid soils and may be affected at soil $\mathrm{pH}$ below 5.5 to 6.0 .

The amount of acid that can theoretically be generated if all the ammonium added in fertilizer is converted to nitrate is 2 equivalents $\mathrm{H}^{+}$per equivalent of $\mathrm{NH}_{4}^{+}-\mathrm{N}$ applied. For the nitrogen sources

\footnotetext{
The author is a soil scientist, USDA, ARS, Southern Plains Range Research Station, 2000-18th Street, Woodward, Okla. 73801 .

Manuscript accepted 20 June 1985.
}

most likely to be used in pasture or range fertilization, ammonium nitrate, urea, and anhydrous ammonia, the theoretical acidification potential is equivalent to $3.57 \mathrm{~kg}$ of $\mathrm{CaCO}_{3}$ per $\mathrm{kg}$ of $\mathrm{N}$ applied (Adams 1984). In practice, soil acidification is usually less than, and is commonly about one half of, the theoretical (Adams 1984, McLean and Brown 1984).

The purpose of this study was to determine the effect of 20 years of low-rate $\mathrm{N}$ fertilization of grassland upon the $\mathrm{pH}$ and lime requirement of a sandy soil. A glasshouse study was then used to assess the effect of the acidified soil upon the growth of 5 forage species commonly used in the southern Great Plains in revegetation of old fields.

\section{Study Area}

The study location was in Harper County, northwest Oklahoma, on the Southern Great Plains Experimental Range. Average annual precipitation is $55 \mathrm{~cm}$; the frost-free period is usually from mid-April to mid-October. The soils are mapped as the Pratt series (sandy, mixed, thermic Psammentic Haplustalfs). The texture of the surface $15 \mathrm{~cm}$ ranged from sandy loam to loamy sand. Organic matter in the surface $15 \mathrm{~cm}$ averages about $1 \%$. The cation exchange capacity of composite soil samples from the surface 15 $\mathrm{cm}$ was $6 \mathrm{me} / 100 \mathrm{~g}$. Native perennial vegetation on the Pratt soils tends to be dominated by sand bluestem (Andropogon gerardii var. paucipilus (Nees) Kunth), switchgrass (Panicum virgatum $L$.), sand dropseed (Sporobolus cryptandrus (Torr.) Gray), blue grama (Bouteloua gracilis (H.B.K.) LAG.), and sand sagebrush (Artemisia filifolia Torr.).

The $1 \times 4-\mathrm{km}$ study area was initially plowed in about 1900 and farmed until 1910 when, because of severe wind erosion, cultivation was stopped and the area allowed to revegetate. In the 1940's the area was again plowed, cropped to annuals for several years, and then seeded to perennial forage species. The success in stand establishment and longevity varied, but by 1982 when the area was sampled, sand dropseed was the most abundant perennial species in these old fields. The old field pastures have been moderately grazed and have not been fertilized.

In the 1950's and early 1960's monocultures of weeping lovegrass or Caucasian bluestem were established in portions of the old fields. These 2 to 5 ha improved pastures were intensively managed (Shoop et al. 1976, Sims and Dewald 1982), receiving an average of $37 \mathrm{~kg} \mathrm{Na} \mathrm{ha}{ }^{-1} \mathrm{yr}^{-1}$ as urea or ammonium nitrate over the period 1963 through 1982. The nitrogen was broadcast annually in April at the rate of 28 to $33 \mathrm{~kg} \mathrm{~N} \mathrm{ha}^{-1}$. In years with higher rainfall in late spring, a second $\mathbf{N}$ application was made in June. The $\mathbf{N}$ fertilized pastures were burned each spring in which enough residue remained to carry a fire, an estimated 1 in 2 years. The old field pastures were not burned.

\section{Methods}

Four sites, each about 2 ha in size, extending from an improved $\mathrm{N}$ fertilized pasture into an old field pasture were sampled. Each site was selected for uniform topography and soils. Two of the $\mathrm{N}$ fertilized pastures were in weeping lovegrass and two in Caucasian bluestem. Within each pasture on each site, 10 soil sampling locations were randomly located. To reduce edge effect, these locations were at least $10 \mathrm{~m}$ from the common fence between the $\mathrm{N}$ fertilized and old field pastures. Soil samples were taken in October 1982 by 
5-cm depth increments to $20 \mathrm{~cm}$ and then by $10-\mathrm{cm}$ increments to $40 \mathrm{~cm}$. The samples were air dried and then screened through a sieve with 2-mm openings. Coarse fragments, which ranged from 0 to $3 \%$ of the sample mass, were discarded.

To determine $\mathrm{pH}, 20 \mathrm{ml}$ of distilled water was added to $10 \mathrm{~g}$ of soil, the mixture was stirred, allowed to stand 1 hour, stirred again and the $\mathrm{pH}$ determined after inserting the electrodes of a $\mathrm{pH}$ meter into the supernatant liquid. To determine the lime requirement, 10 $\mathrm{ml}$ of a $\mathrm{pH} 8.0$ buffer solution of p-nitrophenol, $\mathrm{H}_{3} \mathrm{BO}_{3}, \mathrm{KCl}$ and $\mathrm{KOH}$ (Adams and Evans 1962) was added to the $10-\mathrm{g}$ soil $+20 \mathrm{ml}$ water mixture used in the $\mathrm{pH}$ determinations. The mixture was stirred, allowed to equilibrate 1 hour, stirred again, and the $\mathrm{pH}$ of the liquid determined. Each $0.10 \mathrm{pH}$ unit decrease in the mixture was equal to 0.089 me acid. The acidity generated in the $\mathrm{N}$ fertilized pastures was calculated as the difference in buffer consumed by soil samples from each fertilized pasture minus the buffer consumed by soil samples from the adjacent old field. To make lime requirement calculations on a soil mass/ ha basis, the mean bulk density of 5-cm increments of soil from each pasture was used. The bulk density was measured by $5-\mathrm{cm}$ increments to $15 \mathrm{~cm}$ by the excavation method (Blake 1965) near each sampling point in each pasture. The bulk density of samples taken from deeper than $15 \mathrm{~cm}$ was assumed to be $1.5 \mathrm{~g} \mathrm{~cm}^{-3}$, which was the measured mean bulk density of the 5 to $15-\mathrm{cm}$ increments.

To assess the impact of soil acidification on plant growth a glasshouse study was carried out. Alfalfa (Medicago sativa $\mathrm{L}$. 'Cimarron'), common yellow sweetclover (Melilotus officinalis (L.) Lam.), Old World bluestem (Bothriochloa ischaemum (L.) Keng 'WW-Spar'), weeping lovegrass 'Morpa,' and sand bluestem 'Woodward' were seeded into 3 soils. The soils were from an old field pasture, a $\mathbf{N}$ fertilized pasture, and limed soil from the $\mathrm{N}$ fertilized pasture. The soils were collected to a depth of $5 \mathrm{~cm}$ from near each of the sampling points in the fertilized pasture and the old field pasture of site 3 . Soil from within each pasture was composited, mixed, and air dried. A portion of the soil from the fertilized pasture was limed with $\mathrm{Ca}(\mathrm{OH})_{2}$ (hydrated lime) at the rate of $1.18 \mathrm{~g} \mathrm{Ca}(\mathrm{OH})_{2} \mathrm{~kg}^{-1}$ soil, mixed, watered to field capacity, spread, and allowed to dry in the glasshouse. The limed soil was mixed and put through 3 more wet and dry cycles over a 6-week period to allow the $\mathrm{CA}(\mathrm{OH})_{2}$ to react.

The soils were fertilized with $\mathbf{N}$ and $\mathbf{P}$ to minimize fertility effects from past management. Monocalcium phosphate at the rate of $0.04 \mathrm{~g} \mathrm{P} \mathrm{kg}^{-1}$ soil was mixed into $2-\mathrm{kg}$ batches of soil and placed in individual pots. Pots were seeded to individual species and watered to field capacity. The legume seed was inoculated prior to planting. After seedling emergence, ammonium nitrate was applied in solution to each pot at the rate of $0.05 \mathrm{~g} \mathrm{~N} \mathrm{~kg}^{-1}$ soil. The pots were watered daily with distilled water to bring the soil to field capacity. The plants were thinned to 5 plants/pot. Lighting in the glasshouse was supplemented $14 \mathrm{hr}^{\text {day }}{ }^{-1}$ by high pressure sodium lamps giving an intensity of $340 \mu \mathrm{mol} \mathrm{m} \mathrm{s}^{-1}$ at the soil surface. Glasshouse temperatures were $25 \pm 3^{\circ} \mathrm{C}$. The plants were seeded on 18 January and harvested 28 days later by cutting $1 \mathrm{~cm}$ above the soil surface, freeze dried, and weighed. Four replications were used in the glasshouse study.

Analysis of variance for a randomized block design with subsamples was used to analyze the $\mathrm{pH}$ and liming requirement data for each depth increment in the field study. The herbage yields in the glasshouse study were subjected to analysis of variance by species, and then treatment means within species separated by Tukey's multiple range test. The standard errors of the difference between means in both the field and glasshouse studies are based on $n=4$.

\section{Results and Discussion}

A mean $\mathrm{pH}$ of 5.3 found in the surface $5 \mathrm{~cm}$ of the $\mathrm{N}$ fertilized pastures was significantly lower than the pH of 6.7 in the old fields (Table 1). A measurably lower $\mathrm{pH}$ was found to $20 \mathrm{~cm}$ in the $\mathrm{N}$
Table 1. The soil pH of pastures fertilized with an average of $37 \mathrm{~kg} N$ $\mathrm{ha}^{-1} \mathrm{yr}^{-1}$ for 20 years as compared to soll $\mathrm{pH}$ values in adjacent old fields.

\begin{tabular}{|c|c|c|c|c|}
\hline Depth & $\begin{array}{c}\text { Fertilized } \\
\text { pastures }\end{array}$ & Old fields & $\begin{array}{c}\text { Standard error of } \\
\text { difference } \\
\text { between means }\end{array}$ & $\begin{array}{c}\text { Probability } \\
\text { of }>F\end{array}$ \\
\hline \multicolumn{5}{|l|}{$\mathrm{cm}$} \\
\hline $0-5$ & 5.3 & 6.7 & 0.2 & 0.003 \\
\hline $5-10$ & 5.8 & 6.7 & 0.1 & 0.004 \\
\hline $10-15$ & 6.2 & 6.6 & 0.1 & 0.05 \\
\hline $15-20$ & 6.6 & 6.8 & 0.04 & 0.01 \\
\hline $20-30$ & 6.6 & 6.7 & 0.07 & 0.31 \\
\hline $30-40$ & 6.8 & 6.8 & 0.04 & 0.34 \\
\hline
\end{tabular}

fertilized pastures. These changes in $\mathrm{pH}$ are greater than the $\mathrm{pH}$ changes reported for long-term low-rate $\mathbf{N}$ fertilization of grassland in Kansas (Owensby et al. 1969) and North Dakota (Smika et al. 1961). In the Kansas and North Dakota studies pH was determined on wider $(15 \mathrm{~cm})$ soil depth increments and the soils were finer textured and thus had a greater buffer capacity to resist $\mathrm{pH}$ change than the sandy, low organic matter soils in this study. The localization of the acidification near the surface is in agreement with other studies on acidification of near-neutral soils by fertilizer ammonium nitrification under rangeland (Smika et al. 1961) and minimum till (Mahler and Harder 1984) conditions.

The lime requirement, a quantitative measurement of soil acidification, was significantly increased to a depth of $15 \mathrm{~cm}$ in the $\mathrm{N}$ fertilized pastures (Table 2). When recalculated as one $0-15 \mathrm{~cm}$ increment, the lime requirement in the $\mathrm{N}$ fertilized pastures was 896 $\mathrm{kg} \mathrm{CaCO}_{3} \mathrm{ha}^{-1}$ greater than in the old field pastures. The theoretical maximum amount of acidity that could have been generated by $740 \mathrm{~kg} \mathrm{~N} \mathrm{ha}^{-1}$ applied over 20 years to the $\mathrm{N}$ fertilized pastures was $2,640 \mathrm{~kg} \mathrm{CaCO} \mathrm{ha}^{-1}$. The variability of the lime requirement (C.V. $=54 \%$ ) in this study precludes a close comparison to the lime requirement found in other $\mathbf{N}$ fertilization studies (McLean and

\section{Table 2. The lime requirement of pastures fertilized with an average of 37 $\mathrm{kg} \mathrm{N} \mathrm{ha}{ }^{-1} \mathrm{yr}^{-1}$ for 20 years as compared to the lime requirement of unfertilized old field pastures.}

\begin{tabular}{lcccc}
\hline \hline Depth & $\begin{array}{c}\text { Fertilized } \\
\text { pastures }\end{array}$ & Old fields & $\begin{array}{c}\text { Standard error of } \\
\text { difference } \\
\text { between means }\end{array}$ & $\begin{array}{c}\text { Probability } \\
\text { of }>\text { F }\end{array}$ \\
\hline $\mathrm{cm}$ & $-\mathrm{kg} \mathrm{CaCO}_{3} \mathrm{ha}^{-1}-$ & 339 & \\
$0-5$ & 1021 & 486 & 214 & 0.01 \\
$5-10$ & 703 & 473 & 161 & 0.04 \\
$10-15$ & 545 & 412 & 76 & 0.08 \\
$15-20$ & 536 & 488 & 111 & 0.60 \\
$20-30$ & 1021 & 987 & 206 & 0.51 \\
$30-40$ & 1131 & 1079 & &
\end{tabular}

Brown 1984). The trend is that the magnitude of the lime requirement in relation to the amount of ammonium- $\mathrm{N}$ applied is similar to or less than that reported in other studies. Although nitrification of fertilizer ammonium is assumed to be the major soil acidification factor in this study, other factors may enhance or ameliorate acidification. Recycling of $\mathrm{N}$ as urea in urine, and the decomposition of the increased amount of organic matter produced by fertilization could contribute to acidification. Ammonia volatilization from broadcast $\mathbf{N}$ fertilization is a loss to acidification potential. Pasture burning should produce an alkaline ash which would neutralize some acidity.

Sweetclover had a distinct marginal chlorosis and cupping of leaves when grown in soil taken from the depth of 0 to $5 \mathrm{~cm}$ in the $N$ fertilized pasture. These symptoms of manganese toxicity (Morris and Pierre 1949) were not present on sweetclover grown in limed 
soil from the $\mathbf{N}$ fertilized pasture or in soil from the old field Herbage yields of sweetclover were significantly less when grown in the soil from the $\mathbf{N}$ fertilized pasture than in soil from the old field or limed $\mathbf{N}$ fertilized soil (Table 3). The smaller yield on the unlimed $\mathrm{N}$ fertilized pasture soil was probably due to a combination of aluminum and manganese toxicity resulting from the increased solubility of these elements under acid conditions.

Table 3. Glasshouse herbage yields of 5 forage species as affected by unlimed and limed soil taken from $0-5 \mathrm{~cm}$ in a $\mathrm{N}$ fertilized pature and an adjacent old field.

\begin{tabular}{|c|c|c|c|c|}
\hline & \multicolumn{3}{|c|}{ Soil } & \multirow{3}{*}{$\begin{array}{c}\text { Standard } \\
\text { error of } \\
\text { difference } \\
\text { between means }\end{array}$} \\
\hline & \multicolumn{2}{|c|}{ N Fertilized pasture } & \multirow{2}{*}{$\begin{array}{l}\text { Old field } \\
\text { pH } 6.9\end{array}$} & \\
\hline & $\begin{array}{c}\text { Unlimed } \\
\text { pH } 5.2\end{array}$ & $\begin{array}{c}\text { Limed to } \\
\text { pH } 6.9\end{array}$ & & \\
\hline \multirow{6}{*}{$\begin{array}{l}\text { Sweetclover } \\
\text { Alfalfa } \\
\text { Weeping } \\
\text { lovegrass } \\
\text { Sand bluestem } \\
\text { Old World } \\
\text { bluestem }\end{array}$} & & & $\operatorname{pot}^{-1}$ & \\
\hline & $1.77 b^{1}$ & $3.30 \mathrm{a}$ & $4.02 \mathrm{a}$ & 0.29 \\
\hline & $2.19 \mathrm{~b}$ & $2.15 \mathrm{~b}$ & $2.84 \mathrm{a}$ & 0.22 \\
\hline & $2.29 \mathrm{a}$ & $1.43 \mathrm{~b}$ & $1.80 \mathrm{ab}$ & 0.22 \\
\hline & $0.98 \mathrm{a}$ & $0.70 \mathrm{~b}$ & $0.96 \mathrm{a}$ & 0.09 \\
\hline & $3.50 \mathrm{a}$ & $2.53 \mathrm{~b}$ & $2.47 \mathrm{~b}$ & 0.22 \\
\hline
\end{tabular}

'Means within a species followed by the same letter or letters do not differ significantly at the 0.05 level of probability according to Tukey's test.

Leaves of about one-half of the alfalfa plants grown in the unlimed soil from the $\mathrm{N}$ fertilized pasture had a marginal chlorosis indicating manganese toxicity. Herbage yield of alfalfa grown in the unlimed soil was significantly less than the yield on the old field soil (Table 3). The similar alfalfa yields on the unlimed and limed soils taken from the $\mathbf{N}$ fertilized pasture was unexpected since the sensitivity of alfalfa to acid soils is well known. It may be that the liming treatment resulted in some microsites with high $\mathrm{pH}$ levels due to unreacted $\mathrm{Ca}(\mathrm{OH})_{2}$ even though the $\mathrm{pH}$ of a composite sample after 4 mixing, wetting, and drying cycles was 6.9 .

Yield of warm-season grasses in the glasshouse study was not adversely affected by the acidified soil. Weeping lovegrass produced similar yields on the unlimed soil from the $\mathbf{N}$ fertilized pasture and on the old field soil (Table 3). Sand bluestem followed the same pattern. Old World bluestem produced a greater yield on the unlimed soil from the $\mathrm{N}$ fertilized pasture than on the old field soil. The grasses all produced more herbage on the unlimed than on the limed soil from the $\mathbf{N}$ fertilized pasture.

These glasshouse results indicate that long-term low-rate $\mathrm{N}$ fertilization has acidified the surface of the sandy soil so as to adversely affect growth of sweetclover and alfalfa. Under field conditions the legumes might be less affected than in the glasshouse study as roots may penetrate into less acid subsurface soil. Toxicity effects to legumes under the field $\mathrm{pH}$ conditions shown in Table 1 could probably be negated by mixing the soil to a depth of $20 \mathrm{~cm}$. However, soil mixing posses the risk of exposing the unvegetated sandy soil to wind erosion.
In the longer term, continued use of acid-producing $N$ fertilizers will eventually require that the soil be limed if species sensitive to acid conditions are grown. Effective use of lime requires mixing it into the soil, and again this raises a potential wind erosion problem on the sandy soil. An amelorative action might be to broadcast lime on the soil surface to neutralize some of the acidity as it is generated. This might have some success since the data (Tables 1 and 2) indicate that most of the acid production occurs in the surface $5 \mathrm{~cm}$. A drawback to the latter suggestion is that a higher $\mathrm{pH}$ at the soil surface can result in greater $\mathrm{N}$ volatilization from broadcast ammonium on ammonium-producing fertilizer.

\section{Literature Cited}

Adams, F., and C.E. Evans. 1962. A rapid method for measuring lime requirement of Red-Yellow Podzolic soils. Soil Sci. Soc. Amer. Proc. 26:355-357.

Adams, F. 1984. Crop response to lime in the southern United States. p. 211-265. In: F. Adams (ed) Soil Acidity and Liming, 2nd ed. Amer. Soc. Agron. Madison, Wis.

Berg, W.A., and P.I. Coyne. 1983. Fertilization and water use of improved pasture grasses in western Oklahoma and adjacent areas in Texas. p. 26-35. In: Proceedings Range and Pasture Seeding in the Southern Great Plains. Texas A\&M University Agr. Res. Center, Vernon, Tex.

Blake, C.R. 1965. Bulk density. p. 374-390. In: C.A. Black (ed) Methods of soil analysis. Part I. Amer. Soc. Agron. Madison, Wis.

Foy, C.D. 1984. Physiological effects of hydrogen, aluminum, and manganese toxicities in acid soil. p. 57-97. In: F. Adams (ed) Soil acidity and liming, 2nd ed. Amer. Soc. Agron. Madison, Wis.

Launchbaugh, J.L., C.E. Owensby, J.R. Brethour, and E.F. Smith. 1983. Intensive-early stocking studies on Kansas ranges. Rep. of Prog. 441. Agr. Exp. Sta. Kansas State Univ., Manhattan.

Mahler, R.H., and R.W. Harder. 1984. The influence of tillage methods, cropping sequence, and $\mathbf{N}$ rates on the acidification of a northern Idaho soil. Soil Sci. 137:52-60.

McCoy, D.A., and G.R. Webster. 1977. Acidification of a luvisolic soil caused by low rate, long-term applications of fertilizers and its effects on growth of alfalfa. Can. J. Soil Sci. 57:119-127.

McLean, E.O., and J.R. Brown. 1984. Crop response to lime in the midwestern United States. p. 267-303. In: F. Adams (ed) Soil Acidity and Liming, 2nd ed. Amer. Soc. Agron. Madison, Wis.

Morris, H.D., and W.H. Pierre. 1949. Minimum concentrations of manganese necessary for injury to various legumes in culture solutions. Agron. J. 41:107-112.

Owensby, C.E., K.L. Anderson, and D.A. Whitney. 1969. Some chemical properties of a silt loam soil after 20 years' nitrogen and phosphorus fertilization of smooth bromegrass (Bromus inermis Leyss.). Soil Sci. 108:24-29.

Rogler, G.A., and R.J. Lorenz. 1969. Pasture productivity of crested wheatgrass as influenced by nitrogen fertilization and alfalfa. USDA Tech. Bull, 1402

Rogler, G.A., and R.J. Lorenz. 1974. Fertilization of mid-continent range plants. p. 231-254. In: D. Mays (ed) Forage fertilization. Amer. Soc. Agron. Madison, Wis.

Shoop, M., E.H. McIlvain, and P.W. Voight. 1976. Morpa weeping lovegrass produces more beef. J. Range Manage. 29:101-103.

Smika, D.E., H.J. Hass, G.A. Rogler, and R.J. Lorenz. 1961. Chemical properties and moisture extraction in rangeland soils as influenced by nitrogen fertilization. J. Range Manage. 14:213-216.

Sims, P.L., and C.L. Dewald. 1982. Old World bluestems and their production potential for the Southern Great Plains. USDA-ARS ARM-S-28.

Westerman, R.L. 1981. Factors affecting soil acidity. Solutions 25(3):64-81. 